\title{
Meta Analysis: Effect of Oral Contraceptives on Obesity in Fertile Age Women in Asia
}

\author{
Muhammad Zia Ulhaq'), Eti Poncorini Pamungkasari²), Bhisma Murti') \\ 1)Masters Program in Public Health, Universitas Sebelas Maret \\ 2)Faculty of Medicine, Universitas Sebelas Maret
}

\section{ABSTRACT}

Background: Obesity is a disease with a complex (multi-causal) cause because it involves genetic and environmental factors. Some of them are heredity, individual socio-economic factors, eating patterns (habits), food consumption, physical activity, hormonal, nutritional knowledge, and perception. This study aimed to analyze the effect of oral contraceptives on obesity in women of childbearing age.

Subjects and Method: This was a meta analysis and systematic review from several observational studies. The articles were collected from PubMed, Google Scholar, and Springerlink databases, published from 2000-2020. Data collection used eligibility criteria, including population (P): women of reproductive age, intervention (I): oral contraceptive, comparison (C): non oral contraceptive, and outcome (O): obesity. Keywords used "pil contraception" OR "Pil Contraceptive" AND "Oral Contraceptive" OR "Oral Contraception" AND "Obesity" OR "Overweight" AND" Cross sectional" AND "Cohort" AND "Adjusted Odds Ratio". Selected articles were full text of observational study. These articles were selected by PRISMA flow diagram. Quantitative synthesis was conducted using Review Manager 5.3 program.

Results: A total of 3 articles reviewed in a meta-analysis with subgroup analysis using an observational cohort design showed that oral contraceptives increased the risk of obesity in women of reproductive age $(\mathrm{aOR}=1.14,95 \%$ $\mathrm{CI}=1.03-1.26, \mathrm{p}<0.001)$. A meta-analysis of 4 articles that conducted a subgroup analysis with a cross sectional observational design also showed that oral contraceptives increased the risk of obesity in women of childbearing age (aOR=1.52; 95\% $\mathrm{CI}=0.78-298 ; \mathrm{p}<0.001)$. This meta-analysis combines primary research from Korea, India, Canada, Congo, and the United States of America.

Conclusion: Oral contraceptives increase the risk of obesity.

Keywords: oral contraception, obesity

\section{Correspondence:}

Muhammad Zia Ulhaq. Masters Program in Public Health, Universitas Sebelas Maret, Jl. Ir. Sutami 36A, Surakarta 57126, Central Java. Email: kandaulhaq@gmail.com.

Cite this as:

Ulhaq MZ, Pamungkasari EP, Murti B (2020). Meta Analysis: Effect of Oral Contraceptives on Obesity in Fertile Age Women in Asia. J Matern Child Health. 05(06): 673-682. https://doi.org/10.26911/thejmch.2020.05.06.07.

Journal of Maternal and Child Health is licensed under a Creative Commons Attribution-NonCommercial-ShareAlike 4.o International License.

\section{BACKGROUND}

Overweight and obesity are defined as abnormal or excessive fat accumulation that presents a risk to health. A Body Mass Index (BMI) of more than 25 is considered overweight, and more than 30 is obese. This problem has grown to epidemic proportions, with more than 4 million people dying each year as a result of being overweight or obese in 2017 according to the global disease burden (WHO, 2017).

The increasing prevalence of overweight and obesity in several countries has been described as a global pandemic in 2010, overweight and obesity are estimated to cause 3-4 million deaths, $4 \%$ life years 
lost, and 4\% lifetime years adjusted for disability across world (Fleming, 2014). Globally, the number of adults with a body mass index of $25 \mathrm{~kg} / \mathrm{m}^{2}$ or greater has increased between 1980 and 2013 from $28.8 \%$ to $36.9 \%$ in men, and from $29.8 \%$ to $38 \%$ in women.

Overweight and obesity are major risk factors for a number of chronic diseases, including cardiovascular disease such as heart disease and stroke, which are the leading causes of death worldwide. Being overweight can also lead to diabetes and related conditions, including blindness, amputation of limbs, and the need for dialysis (who, 2017).

Obesity is a disease with a very complex (multi-causal) cause because it involves genetic and environmental factors (Balaban \& Silva 2004). Some of them are heredity, individual socio-economic factors, eating patterns (habits), food consumption, physical activity, hormonal, nutritional knowledge, and perception. Although they do not directly affect nutritional status, these factors can encourage obesity (Parengkuan, 2010).

Contraceptive prevalence in 2019 was $23.7 \%$ of women using contraception, 219 million women used sterilization. The other three methods have more than 100 million users worldwide, male condoms (189 million), IUDs (159 million) and pills (151 million). Overall, $45.2 \%$ of contraceptive users rely on permanent or long-term methods (female and male sterilization, IUD, implants), $46.1 \%$ on short-acting methods (such as male condoms, pills, injections and other modern methods) and 8.7\% on traditional methods (withdrawal, rhythm method, and other traditional methods) (United Nation, 2019).

Based on these data, the authors are interested in knowing how big is the effect of oral contraceptives on obesity in women of childbearing age based on previous research?.

\section{SUBJECTS AND METHOD}

\section{Study Design}

This was a systematic review and meta-analysis. The articles used in this study were obtained from several databases including PubMed, Google Scholar and Springerlink. The keywords to find articles are as follows: "Contraception Pills" OR "Contraceptive Pills" AND "Oral Contraceptive" OR "Oral Contraception" AND "Obesity" OR "Overweight" AND "Cross sectional" AND "Cohort" AND "Adjusted Odds Ratio "

\section{Inclusion Criteria}

The articles included in this study are full paper articles with an Observational study design and in English. The appropriate article should mention the population of women of childbearing age, interventions for the use of oral contraceptives with obesity outcomes. Articles must be published in 2000-2020 with multivariate OR.

\section{Exclusion Criteria}

The article published in this study is an article with the subject of infertile women with obesity. His articles are those conducted with non-observational results.

\section{Operational Definition of Variables}

The article search was carried out by considering the eligibility criteria defined using the PICO model. The population in the study were women of childbearing age with intervention in the form of oral contraceptives, comparison of non-oral contraceptives and obesity outcomes.

Oral contraceptives are substances contained in contraceptives in the form of pill/ oral contraceptives.

Obesity is body weight measured by a Body Mass Index that exceeds >30 (kg/ $\mathrm{m}^{2}$ ). 


\section{Data Analysis}

Data processing was carried out by the Review Manager (RevMan 5.3) by calculating the effect size and heterogeneity to determine which research models were combined and formed the final metaanalysis result.

\section{RESULTS}

The process of searching for articles by searching through a database with journals can be seen in Figure 1. Figure 2 shows the areas where articles were taken according to the inclusion criteria. Articles obtained from 2 continents of Africa, 14 articles from the continent of Asia.

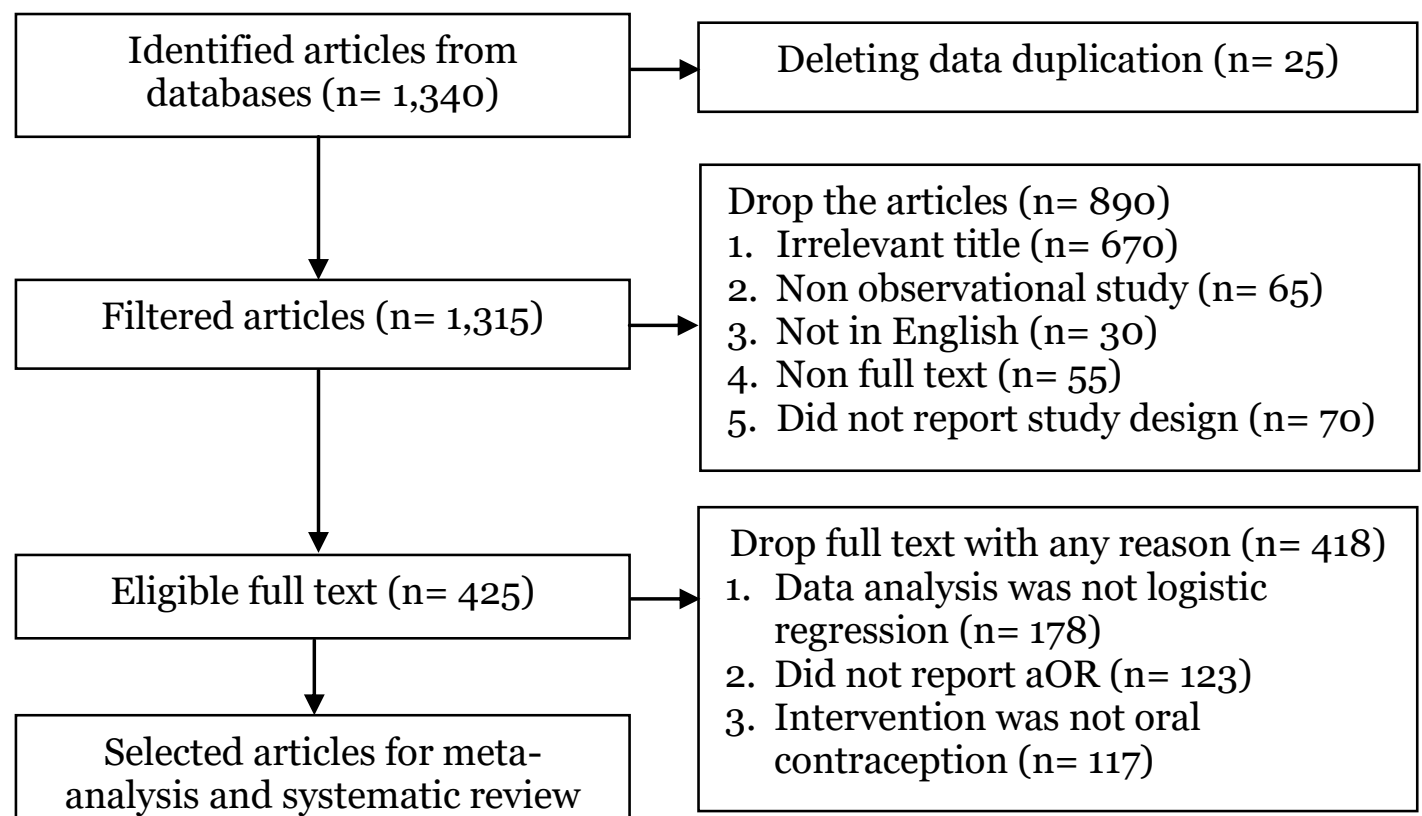
$(n=7)$

Figure 1. PRISMA flow diagram

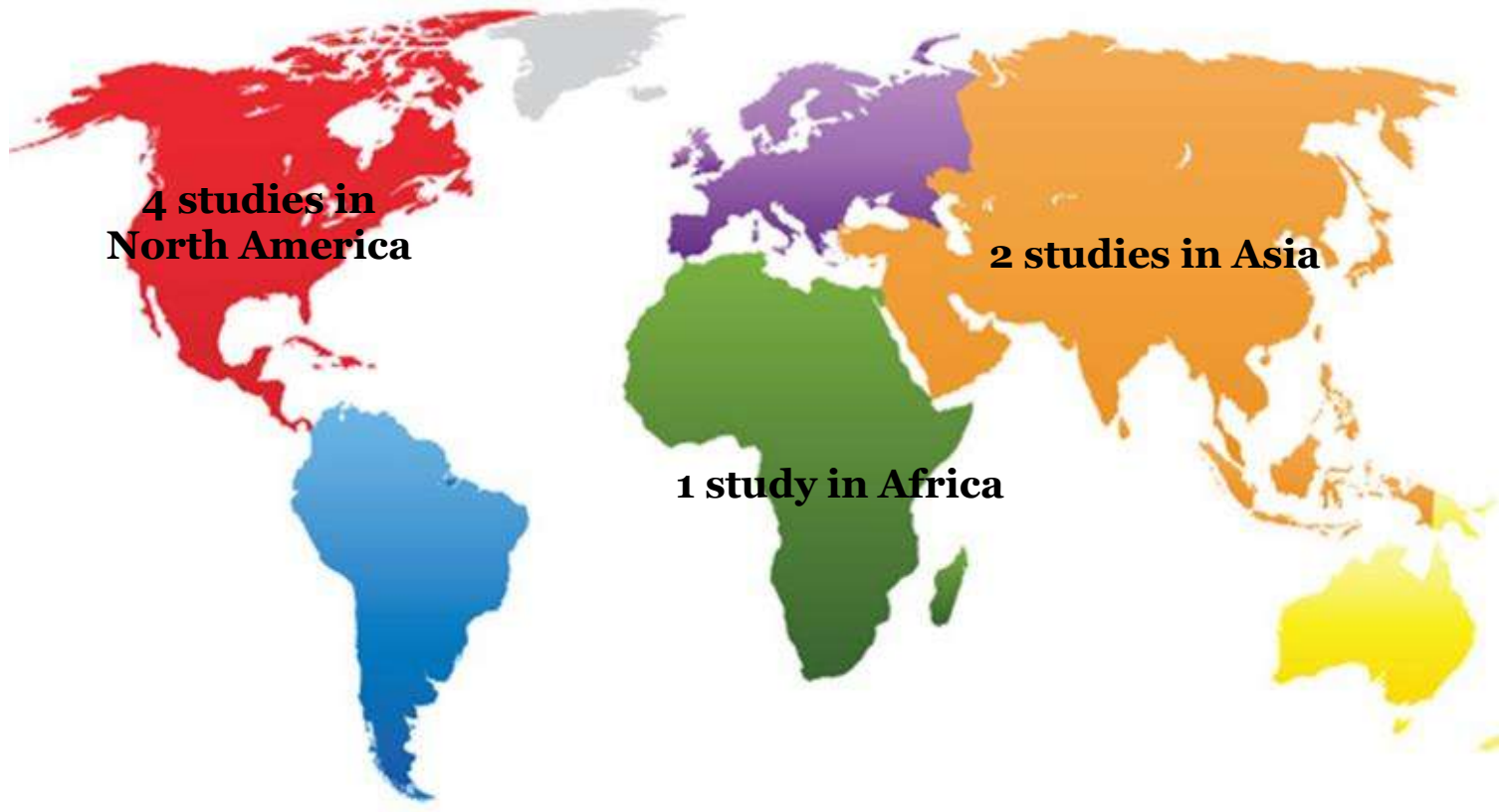

Figure 2. Map of study areas on the effect of oral contraceptive on obesity 
1. Oral contraception on the risk of obesity in women of childbearing age

\section{a. Summary Source}

Table 1. Descriptions of primary studies included in the meta-analysis

\begin{tabular}{|c|c|c|c|c|c|c|c|c|}
\hline $\begin{array}{c}\text { Author } \\
\text { (year) }\end{array}$ & Title & Country & $\begin{array}{l}\text { Study } \\
\text { Design }\end{array}$ & Sample & $\begin{array}{c}\mathbf{P} \\
\text { Population }\end{array}$ & $\begin{array}{c}\text { I } \\
\text { Intervention }\end{array}$ & $\begin{array}{c}\mathrm{C} \\
\text { Compa- } \\
\text { rison }\end{array}$ & $\begin{array}{c}\text { O } \\
\text { Outcome }\end{array}$ \\
\hline $\begin{array}{l}\text { Paul } \\
\text { Mawaw } \\
(2017)\end{array}$ & $\begin{array}{l}\text { A cross-sectional study on obesity and } \\
\text { related risk factors among women of } \\
\text { the central market of Lusonga in } \\
\text { Lubumbashi, Democratic Republic of } \\
\text { Congo }\end{array}$ & Congo & $\begin{array}{l}\text { Cross } \\
\text { sectional }\end{array}$ & 430 & $\begin{array}{l}\text { Women of } \\
\text { childbearing age }\end{array}$ & $\begin{array}{l}\text { Oral } \\
\text { Contraception }\end{array}$ & Placebo & Obesity \\
\hline $\begin{array}{l}\text { Agarwal, } \\
\text { S (2011) }\end{array}$ & $\begin{array}{l}\text { Does Contraceptive Use Effect } \\
\text { Overweight/Obesity among Indian } \\
\text { Women?Findings from a Nationwide } \\
\text { Cross Sectional Survey }\end{array}$ & India & $\begin{array}{l}\text { Cross } \\
\text { sectional }\end{array}$ & 75,554 & $\begin{array}{l}\text { Women of } \\
\text { childbearing age }\end{array}$ & $\begin{array}{l}\text { Oral } \\
\text { Contraception }\end{array}$ & Placebo & Obesity \\
\hline $\begin{array}{l}\text { Kathryn } \\
\text { Wilkins } \\
\text { (2000) }\end{array}$ & Oral Contraceptive use. & Canada & $\begin{array}{l}\text { Cross } \\
\text { sectional }\end{array}$ & 21,996 & $\begin{array}{l}\text { Women of } \\
\text { childbearing age }\end{array}$ & $\begin{array}{l}\text { Oral } \\
\text { Contraception }\end{array}$ & Placebo & Obesity \\
\hline $\begin{array}{l}\text { Su-Hsun } \\
\text { Liu } \\
(2012)\end{array}$ & $\begin{array}{l}\text { Oral contraceptive pill use is associated } \\
\text { with reduced odds of nonalcoholic fatty } \\
\text { liver disease in menstruating women: } \\
\text { results from NHANES III: }\end{array}$ & USA & $\begin{array}{l}\text { Cross } \\
\text { sectional }\end{array}$ & 4,338 & $\begin{array}{l}\text { Women of } \\
\text { childbearing age }\end{array}$ & $\begin{array}{l}\text { Oral } \\
\text { Contraception }\end{array}$ & Placebo & Obesity \\
\hline $\begin{array}{l}\text { Boyoung } \\
\text { Park } \\
(2006)\end{array}$ & $\begin{array}{l}\text { Oral Contraceptive Use, Micronutrient } \\
\text { Deficiency, and Obesity among } \\
\text { Premenopausal Females in Korea: The } \\
\text { Necessity of Dietary Supplements and } \\
\text { Food Intake Improvement }\end{array}$ & Korea & Cohort & 111,592 & $\begin{array}{l}\text { Women of } \\
\text { childbearing age }\end{array}$ & $\begin{array}{l}\text { Oral } \\
\text { Contraception }\end{array}$ & Placebo & Obesity \\
\hline $\begin{array}{l}\text { Elizabeth } \\
\mathrm{T}(2014)\end{array}$ & $\begin{array}{l}\text { Pharmacologic Sex Hormones in } \\
\text { Pregnancy in Relation to Offspring } \\
\text { Obesity }\end{array}$ & USA & Cohort & 34,419 & $\begin{array}{l}\text { Women of } \\
\text { childbearing age }\end{array}$ & $\begin{array}{l}\text { Oral } \\
\text { Contraception }\end{array}$ & Placebo & Obesity \\
\hline $\begin{array}{l}\text { Larissa R } \\
\text { (2006) }\end{array}$ & $\begin{array}{l}\text { Body Mass Index and Risk for Oral } \\
\text { Contraceptive Failure: A Case-Cohort } \\
\text { Study in South Carolina }\end{array}$ & USA & Cohort & 358 & $\begin{array}{l}\text { Women of } \\
\text { childbearing age }\end{array}$ & $\begin{array}{l}\text { Oral } \\
\text { Contraception }\end{array}$ & Placebo & Obesity \\
\hline
\end{tabular}


a. Forest Plot

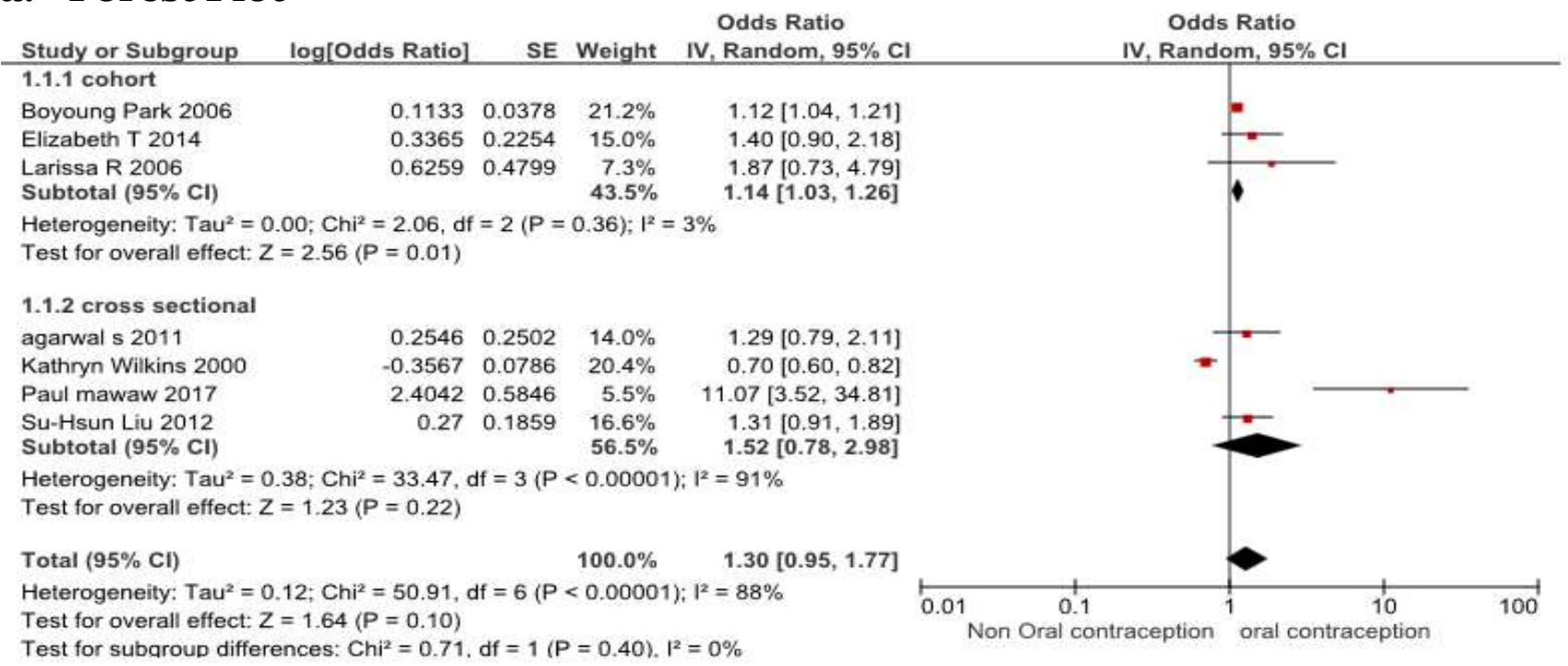

Figure 3. Forest plot of the effect of oral contraceptive on obesity

Interpretation of the results from the meta-analysis process can be seen through a forest plot. Figure 4.5 shows that the results of the subgroup analysis in the cohort study, users of oral contraceptives

\section{b. Funnel Plot}

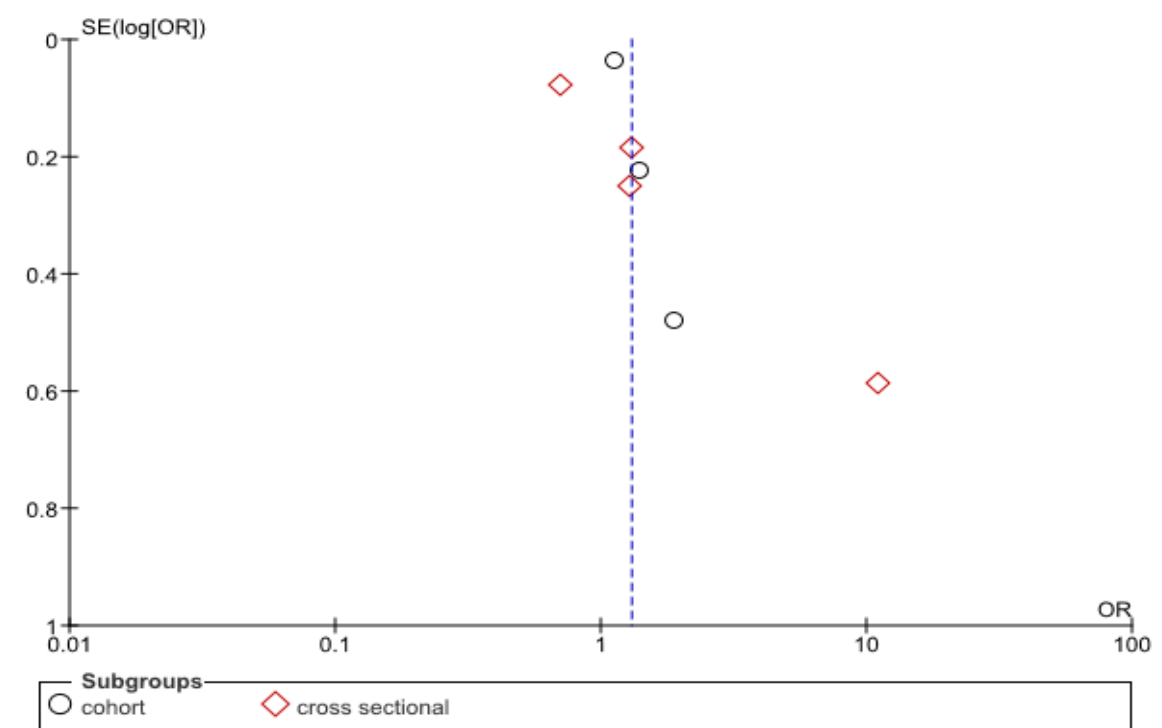

Figure 4. Funnel plot of the effect of oral contraceptive on obesity

While the results of subgroup analysis in a cross-sectional study, users of oral contraceptives had a $\mathbf{1 . 5 2}$ times risk of obesity compared to those who did not use oral contraceptives and this was statistically had a 1.14 times risk of experiencing obesity compared to those who did not use oral contraceptives and this was statistically significant $(\mathrm{p}<0.001)$. The heterogeneity of the research data showed $\mathrm{I}^{2}=3 \%$. 
Table 3. Critical Appraisal Skills Programme (CASP) for Cohort Study

\begin{tabular}{|c|c|c|c|}
\hline \multirow[t]{2}{*}{ Checklist Questions } & \multicolumn{3}{|c|}{$\begin{array}{c}\text { Publication } \\
\text { (Author and Year) }\end{array}$} \\
\hline & $\begin{array}{c}\text { Boyoung Park } \\
\text { (2006) }\end{array}$ & $\begin{array}{c}\text { Elizabeth T } \\
\text { (2014) }\end{array}$ & $\begin{array}{c}\text { Larissa R } \\
(2006)\end{array}$ \\
\hline Does this research address clearly focused issues? & 1 & 1 & 1 \\
\hline Was the group included in an acceptable way? & 1 & 1 & 1 \\
\hline Is exposure measured accurately to minimize bias? & 1 & 1 & 1 \\
\hline Are the results measured accurately to minimize bias? & 1 & 1 & 1 \\
\hline Have the authors identified all the important confounding factors? & 1 & 1 & 1 \\
\hline Was the follow-up to the subject of this study complete? & 1 & 1 & 1 \\
\hline What are the results of this study? & 1 & 1 & 1 \\
\hline How precise is the result? & 1 & 1 & 1 \\
\hline Do you believe in the results? & 1 & 1 & 1 \\
\hline Can the results be applied to the local population? & 1 & 1 & 1 \\
\hline Are the results of this study consistent with other available evidence? & 1 & 1 & 1 \\
\hline What are the implications of this study for practice? & 1 & 1 & 1 \\
\hline Total & 12 & 12 & 12 \\
\hline
\end{tabular}

Note: Yes $=1$, No $=0$

Table 4. Critical appraisal checklist for cross-sectional study

\section{Checklist Questions}

Does this objective clearly address the focus / research problem?

Is the cross-sectional research method suitable for answering research questions?

Is the method of selecting research subjects clearly written?

Does the sampling method create bias (selection)?

Does the research sample taken represent the designated population?

Was the sample size based on pre-study considerations?

Was a satisfactory response achieved?

Are the research instruments valid and reliable?
Publlication

(Author and Year)

\begin{tabular}{cccc}
\multicolumn{4}{c}{ (Author and Year) } \\
\hline $\begin{array}{c}\text { Paul Mawaw } \\
\text { et al (2017) }\end{array}$ & $\begin{array}{c}\text { Agarwal } \\
\text { (2011) }\end{array}$ & $\begin{array}{c}\text { Kathryn } \\
\text { (2000) }\end{array}$ & $\begin{array}{c}\text { Su-Hsun } \\
\text { (2012) }\end{array}$ \\
\hline 1 & 1 & 1 & 1 \\
1 & 1 & 1 & 1 \\
1 & 1 & 1 & 1 \\
1 & 1 & 1 & 1 \\
1 & 1 & 1 & 1 \\
0 & 0 & 0 & 0 \\
1 & 1 & 1 & 1 \\
1 & 1 & 1 & 1
\end{tabular}


Ulhaq et al./ Effect of Oral Contraceptives on Obesity

Is statistical significance assessed?

Are confidence intervals given for the main outcome?

Are there any confounding factors that have not been taken into account?

Are the results applicable to your research?

Total

Note: Yes $=1$, No $=0$ 


\section{DISCUSSION}

This research is a systematic study and meta-analysis. The purpose of this study was to obtain conclusions from various similar studies regarding the effect of oral contraception on obesity in women of childbearing age. Research that discusses obesity data is considered important. The number of relevant research published and accessible is still small and also has data access problems (data duplication) (Murti, 2018). Most of the statistical results reported are in percentage or crude Odd Ratio (cOR), where research does not control for confounding factors (confounding factors).

Counding factors affect the relationship or effect of exposure to the occurrence of disease estimated by the study is not the same as the relationship or effect that actually occurs in the target population, aka invalid study results (Murti, 2018). This systematic study study and meta-analysis used research that controlled for counfounding factors which could be seen from the study inclusion requirements, namely multivariate analysis and the statistical result reported was the adjusted odds ratio (aOR).

Estimates of combined oral contraceptives with obesity were analyzed using the RevMan 5.3 application using the generic inverse variance method. This method is used to analyze data in the form of rate (rate), time-to-event (time-to-event), hazard ratio, ordinal scale, adjusted estimate, average difference, average (difference of mean) or ratio of average (ratio of mean).

The results of the systematic study and meta-analysis are presented in the form of a forest plot and a funnel plot. The forest plot shows an overview of the information from each of the studies examined in the meta-analysis, and a calm estimate of the overall results (Murti, 2018). The forest plot shows visually the amount of variation (heterogeneity) between study results (Akobeng in Murti, 2018).

A funnel plot is a diagram that is included in the meta-analysis used to demonstrate possible publication bias. The funnel plot shows the relationship between the study effect size and the sample size or standard error of the effect size from the various studies studied (Murti, 2018).

Funnel plots describe visually the amount of variation (heterogeneity) (Akobeng, 2005 in Murti, 2018). The funnel plot shows the relationship between the effect size of the study and the sample size of the various studies studied, which can be measured in a number of different ways (Murti, 2018).

\section{The effect of oral contraceptives on the increased risk of obesity in women of childbearing age.}

The results of the forest plot research article with observational cohort design using subgroup analysis showed that women of reproductive age who used oral contraceptives had a 1.14 times risk of obesity compared to women who did not use oral contraceptives and the results were statistically significant $(\mathrm{aOR}=1.14 ; 95 \% \mathrm{CI}=1.03$ to 1.26; $\mathrm{p}<0.001)$. Meanwhile, the research article with a cross-sectional observational design using subgroup analysis showed that pregnant women with unplanned pregnancies had a 1.52 times risk of experiencing antenatal depression compared to pregnant women with planned pregnancies and the results were statistically significant $(\mathrm{aOR}=$ 1.52; $95 \% \mathrm{CI}=0.78$ to $2.98 ; \mathrm{p}<0.001$ ).

This is supported by Jansen et.al (2014) which states that oral contraceptives affect obesity at initial use with adjusted odds ratios (OR: 0.75, 95\% CI: 0.53 to 1.08), similar results were revealed. from the research of Susanna et al., (2016) that the use of oral contraceptives is the cause of 
obesity with the results (aOR: 11.87, 95\% confidence interval CI: 5.94 to 23.74).

In line with the research conducted by Sugiharti (2005) which states that the use of contraceptive hormones causes the risk of obesity (OR: $3.17,95 \% \mathrm{CI}: 1.2$ to 8.5 ). It was also reported that combination pill users appeared to have the highest risk, followed by implant users, while the risk of using implants was the same as those using non-hormonal contraceptives. In addition, the increased risk of obesity in hormonal contraceptive users remained significant after controlling for age, parity, initial body weight, socioeconomic status, energy intake and energy output as well as obesity in parents.

A meta-analysis conducted using 3 articles originating from Korea, North Carolina and South California with an observational cohort design using subgroup analysis showed that women of childbearing age using oral contraceptives had a 1.14 times risk of obesity compared with women not using oral contraceptives and the results were statistically significant $(\mathrm{aOR}=1.14 ; 95 \% \mathrm{CI}=1.03$ to $1.26 ; \mathrm{p}$ $<0.001)$.

Meta-analysis conducted using 4 articles originating from Congo, India, Canada and USA with a cross-sectional observational design using subgroup analysis showed that pregnant women with unplanned pregnancies were $\mathbf{1 . 5 2}$ times more likely to experience antenatal depression than those with planned pregnancies and the results were significant. statistically $(\mathrm{aOR}=1.52 ; 95 \% \mathrm{CI}=0.78$ to $2.98 ; \mathrm{p}$ $<0.001)$.

\section{AUTHOR CONTRIBUTION}

Ulhaq is the main researcher who selects the topic, explores and collects research data. Eti Poncorini and Bhisma Murti played a role in analyzing data and reviewing research documents.

\section{CONFLICT OF INTEREST}

There is no conflict of interest in this study.

\section{FUNDING AND SPONSORSHIP}

This study is self-funded.

\section{ACKNOWLEDGEMENT}

We are very grateful to the database providers PubMed, Google Scholar and Springer Link.

\section{REFERENCE}

Balaban G, Silva GAP (2004). Protective effect of breastfeeding against childhood obesity. J Pediatr (Rio J). 80(1): 71-6. PMID: 14978543.

Jansen E (2013). Pharmacologic sex hormone use before and in early pregnancy in relation to birth and early childhood anthropometric outcomes. University of North Carolina at Chapel Hill. https://doi.org/10.17615/wnx5-aqo3.

Murti B (2018). Prinsip dan Metode Riset Epidemiologi (5th ed) (Principles and Methods of Epidemiological Research (5th ed). Surakarta: Program Studi Ilmu Kesehatan Masyarakat, Program Pascasarjana, Universitas Sebelas Maret

Siswanto. (2010). Systemic review sebagai metode penelitian untuk mensintesis hasil-hasil penelitian (Sebuah Pengantar) (Systematic Review as a Research Method for Synthesizing Research Results (An Introduction)). Surabaya: Pusat Penelitian dan Peng embangan Sistem dan Kebijakan Kesehatan.

Stubblefield P, Carr-Ellis S, Kapp N (2007). In: Berek \& Novak’s Gynecology. 14. 
Berek JS, editor. Philadelphia, PA: Lippincott Williams \& Wilkins

Sugiharti S, Hadi H, Julia M (2005). Hormonal contraception as a risk factor for obesity. Med J Indones. 14: 163-8.

Vickery Z, Madden T, Zhao Q, Secura GM, Allsworth JE, Peipert JF (2013). Weight change at 12 months in users of three progestin-only contraceptive methods. Contraception. 88:503-08.

WHO (2017). Obesity. World Health Organization, https://www.who.int/health-topics/obesity\#tab=tab_1.

WHO (2020). Obesity and Overweight, World Health Organization, https://- www.who.int/news-room/fact-sheets/detail/obesity-and-overweight.

Wijayanti (2006). Perbedaan peningkatan berat badan antara akseptor keluarga berencana suntik progesteron tunggal dan kombinasi progesteron estrogen di klinik kebidanan dan reproduksi bahagia Surakarta (Differences in weight gain between family acceptors planning to inject progesterone single and progesterone combination estrogen in obstetrics and happy reproduction clinic, Surakarta). UNS. Surakarta. 